This item was submitted to Loughborough's Research Repository by the author.

Items in Figshare are protected by copyright, with all rights reserved, unless otherwise indicated.

\title{
Use of organic reductants to lower brightener consumption in acid copper electroplating bath utilising catalytic anodes
}

PLEASE CITE THE PUBLISHED VERSION

\section{PUBLISHER}

(C) Maney Publishing / Institute of Metal Finishing

\section{VERSION}

VoR (Version of Record)

\section{LICENCE}

CC BY-NC-ND 4.0

\section{REPOSITORY RECORD}

Gabe, D.R., and Andrew J. Cobley. 2009. "Use of Organic Reductants to Lower Brightener Consumption in Acid Copper Electroplating Bath Utilising Catalytic Anodes". figshare. https://hdl.handle.net/2134/4150. 
This item was submitted to Loughborough's Institutional Repository (https://dspace.lboro.ac.uk/) by the author and is made available under the following Creative Commons Licence conditions.

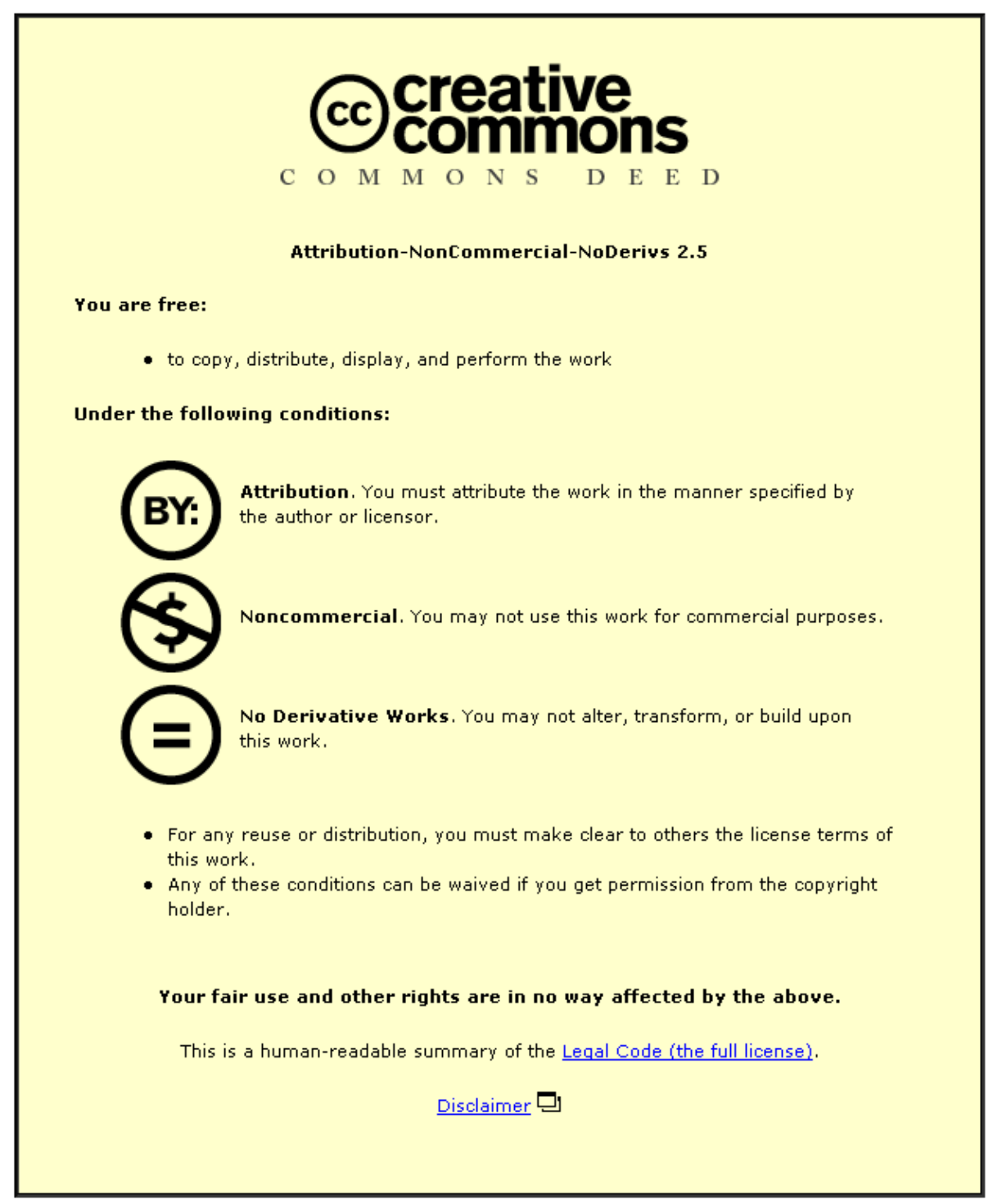

For the full text of this licence, please go to: http://creativecommons.org/licenses/by-nc-nd/2.5/ 


\title{
Use of organic reductants to lower brightener consumption in acid copper electroplating bath utilising catalytic anodes
}

\begin{abstract}
A. J. Cobley ${ }^{1}$ and D. R. Gabe ${ }^{2}$
Catalytic anodes are an enabling technology for high speed, horizontal acid copper electroplating. However, their usage is associated with high additive oxidation rates which can be problematic in terms of cost and control of the electrolyte. The addition of certain 'organic reductants' to the electroplating solution has been found to have a dramatic effect on brightener consumption when catalytic anodes are employed. This paper reports an investigation of three such compounds having varying functionality with respect to brightener oxidation. It was found that the ability of a particular organic reductant to influence brightener oxidation was related to its electrochemical properties on a particular anode material. However, it is postulated that the species' mechanism of oxidation and its anti-oxidant properties may also be important factors.
\end{abstract}

Keywords: Copper electroplating, Anode, Brightener, Ascorbic acid

\section{Introduction}

Insoluble anodes composed of platinised titanium, iridium dioxide, ruthenium dioxide, mixed metal oxides (MMOs, which are often mixtures of these three with the addition of metals such as tantalum and rhenium, etc.) and boron doped diamond (BDD) are often referred to as catalytic anodes and are finding niches in a wide variety of industrial processes and environments. ${ }^{1}$ Previous papers ${ }^{2,3}$ have described how the use of these types of electrode (particularly when supplied as a high surface area mesh) are an enabling technology for the development of horizontal, high speed acid copper electroplating for printed circuit board (PCB) manufacture. However, high additive consumption rates can be associated with the utilisation of catalytic anodes in acid copper sulphate plating electrolytes ${ }^{4}$ and this can be a major drawback to these systems. For this reason various workers have investigated means of overcoming the problem of high brightener consumption rates when employing catalytic anodes using, for example, the iron redox couple $e^{5,6}$ and modified anodes. ${ }^{7}$

This paper describes a novel technique ${ }^{8-12}$ whereby so called 'organic reductants' are added to the acid copper electrolyte and, in some cases, were found to cause a dramatic drop in brightener consumption rate when monitored using methods such as the Hull cell and high performance liquid chromatography (HPLC). Electrochemical studies of the oxidation of the organic reductants and the brighteners on a range of catalytic

${ }^{1}$ Formerly Rohm and Haas Electronic Materials Europe Ltd, Coventry, UK; current address, Coventry University, Sonochemistry Centre, Coventry CV1 5FB, UK

2IPTME, Loughborough University, LE11 3TU, UK

*Corresponding author, email aa2266@coventry.ac.uk anode materials were also carried out, the results from which can, to some extent, be correlated to the plating tests. L-ascorbic acid was found to have an exceptional ability to lower brightener oxidation and possible mechanisms for this behaviour are postulated.

\section{Experimental}

In the initial phase of this work, approximately forty prospective organic reductants were screened for favourable electrochemical properties using anodic polarisation techniques. This paper details experiments for three of those that demonstrated differing levels of functionality namely, L-ascorbic acid, hydroxylamine sulphate and fructose.

\section{Electrolyte}

The electrolyte used in these experiments was comprised of the following basic inorganic matrix:

(i) $80 \mathrm{~g} \mathrm{~L}^{-1}$ copper sulphate pentahydrate $\left(\mathrm{CuSO}_{4}\right.$. $\left.5 \mathrm{H}_{2} \mathrm{O}\right)$

(ii) $225 \mathrm{~g} \mathrm{~L}^{-1}$ sulphuric acid $\left(\mathrm{H}_{2} \mathrm{SO}_{4}\right)$

(iii) $50 \mathrm{ppm}$ chloride $\left(\mathrm{Cl}^{-}\right)$(as $\left.\mathrm{HCl}\right)$

(iv) 'Carrier' (5\% of Rohm and Haas Electroposit M) was also added to the solution along with a typical disulphide type brightener commonly found in acid copper plating formulations.

\section{Anodes}

The anodes investigated were coded as shown below:

(i) $\mathrm{C} 2$ - iridium dioxide, plate (Magneto Chemie)

(ii) $\mathrm{C} 4$ - platinised titanium, plate (Magneto Chemie)

(iii) $\mathrm{S} 2$ - ruthenium dioxide, plate (De Nora)

(iv) $\mathrm{Cu}-$ copper $(0 \cdot 03-0 \cdot 08 \% \mathrm{P})$, cast $(\mathrm{McGean}$ Rohco)

(v) $\mathrm{PbO}_{2}$ - lead dioxide, cast (McGean Rohco) 


\section{Determination of brightener consumption rates}

Brightener consumption was determined by two methods.

\section{Hull cell}

The Hull cell test has been used for many years as a method for visually testing the quality of electroplated deposits over a wide range of current densities. In the case of disulphide type brighteners, it has been found that, within certain concentration ranges, as the brightener concentration in the electrolyte is increased, so the current density at which a bright deposit can be obtained also rises. While this is a vast over simplification of the true situation, it is generally true at typical working bath concentrations of brightener. Thus, by plating a Hull cell panel and measuring the length of the panel that exhibited deposit having a burn or matt (i.e. non-bright) finish, an estimate of the brightener activity can be obtained.

Throughout this work the anodes used in the Hull cell were of dimension $7.5 \times 5.5 \mathrm{~cm}$ and a brushed piece of copper clad laminate $(7.5 \times 10.0 \mathrm{~cm})$ was employed as the cathode. A magnetic stirrer was placed in the bottom of the Hull cell to provide constant agitation.

A brightener concentration of $1 \mathrm{mg} \mathrm{L}^{-1}$ was utilised and a current of $3 \mathrm{~A}$ for $10 \mathrm{~min}$ was applied. The percentage burn on these Hull cell panels was then measured to estimate brightener activity. It should be noted that when the burn/matt area on the Hull cell panel exceeds about $50-60 \%$ the brightener is virtually depleted.

HPLC

Although it may be seen that the Hull cell is a useful method for the study of brightener oxidation at catalytic anodes, the method does not allow for much differentiation to be made between various consumption rates except perhaps 'high' and 'low'.

A Hewlett Packard 1050 series HPLC was utilised to determine the brightener concentration in the electrolyte before and after plating. It incorporated a Phenomenex Kingsorb $5 \mathrm{C}_{18}$ separating column, a mixture of sulphuric acid and acetonitrile as eluent and a UV detector.
The cathode comprised a piece of copper foil which had been previously scrubbed in pumice cleaner and dipped in 10\% sulphuric acid. The cathode current density was $2 \mathrm{~A} \mathrm{dm}^{-2}$ and a magnetic stirrer was employed for solution agitation. The catalytic anode under test completed the circuit (current density $11.4 \mathrm{~A} \mathrm{dm}^{-2}$ ). At the beginning of the electrolysis time, $\sim 100 \mathrm{mg} \mathrm{L}^{-1}$ brightener was added to the plating vessel. The organic reductants were added to the plating cell at a concentration of $2 \mathrm{~g} \mathrm{~L}^{-1}$.

\section{Anodic polarisation}

Anodic polarisation measurements employed an EG\&G Par 273 potentiostat that was driven by EG\&G Soft Corr M352 corrosion measurement and analysis software (Version $4 \cdot 23$ ).

The electrochemical cell comprised a counter electrode (brushed copper laminate) separated by a ceramic frit from the main body of the cell. The working electrode was a rotating disc electrode (RDE) made from a disc (of area $0 \cdot 196 \mathrm{~cm}^{2}$ ) punched from a sample of the anode material under test and spun at $1600 \mathrm{rev} \mathrm{min}^{-1}$. The reference was a saturated calomel electrode (SCE) and anodic polarisation scans were carried out between 0.05 and $2.00 \mathrm{~V}$ with a scan rate of $10 \mathrm{mV} \mathrm{s}^{-1}$.

\section{Results}

\section{Brightener consumption study using Hull cell}

Three organic reductants were used to generate the data given in Table 1 and summarised in Fig. 1. L-ascorbic acid reduced brightener consumption on anodes $\mathrm{C} 2, \mathrm{C} 4$ and $\mathrm{S} 2$ at the $20 \mathrm{mg} \mathrm{L}^{-1}$ level, but a higher concentration was required for anode $\mathrm{PbO}_{2}$. Hydroxylamine sulphate shows functionality on all the anodes but at least $500 \mathrm{mg} \mathrm{L}^{-1}$ needed to be be added to the electrolytes to show a significant effect except in the case of anode $\mathrm{PbO}_{2}$ where $4 \mathrm{~g} \mathrm{~L}^{-1}$ is required. Fructose was tested at $20 \mathrm{~g} \mathrm{~L}^{-1}$ and had no effect on any of the anodes apart from $\mathrm{C} 4$.

Table 1 Effect of organic reductants on brightener oxidation by different Hull cell anodes

Burn/matt area on Hull cell after $10 \mathrm{~min}, \%$

\begin{tabular}{|c|c|c|c|c|c|c|c|}
\hline \multicolumn{8}{|l|}{ Concentration } \\
\hline Compound & $20 \mathrm{~g} \mathrm{~L}^{-1}$ & $4 \mathrm{~g} \mathrm{~L}^{-1}$ & $500 \mathrm{mg} \mathrm{L}^{-1}$ & $100 \mathrm{mg} \mathrm{L}^{-1}$ & $20 \mathrm{mg} \mathrm{L}^{-1}$ & $10 \mathrm{mg} \mathrm{L}^{-1}$ & $5 \mathrm{mg} \mathrm{L}^{-1}$ \\
\hline \multirow{2}{*}{\multicolumn{8}{|c|}{ Hull cell anode $\mathrm{C} 2$}} \\
\hline & & & & & & & \\
\hline L-ascorbic acid & & & & & 45 & 51 & 68 \\
\hline Fructose & 99 & & & & & & \\
\hline Hydroxylamine sulphate & & 42 & 49 & & & & \\
\hline \multicolumn{8}{|l|}{ Hull cell anode C4 } \\
\hline L-ascorbic acid & & & & 40 & 37 & 39 & 70 \\
\hline Fructose & 67 & & & & & & \\
\hline Hydroxylamine sulphate & & & 45 & 65 & & & \\
\hline \multicolumn{8}{|l|}{ Hull cell anode S2 } \\
\hline L-ascorbic acid & & & & & 55 & & 98 \\
\hline Fructose & 100 & & & & & & \\
\hline Hydroxylamine sulphate & & 20 & 40 & & 100 & & \\
\hline \multicolumn{8}{|l|}{ Hull cell anode $\mathrm{PbO}_{2}$} \\
\hline L-ascorbic acid & & & 50 & & 96 & & \\
\hline Fructose & 100 & & & & & & \\
\hline Hydroxylamine sulphate & 38 & 40 & 75 & & & & \\
\hline
\end{tabular}




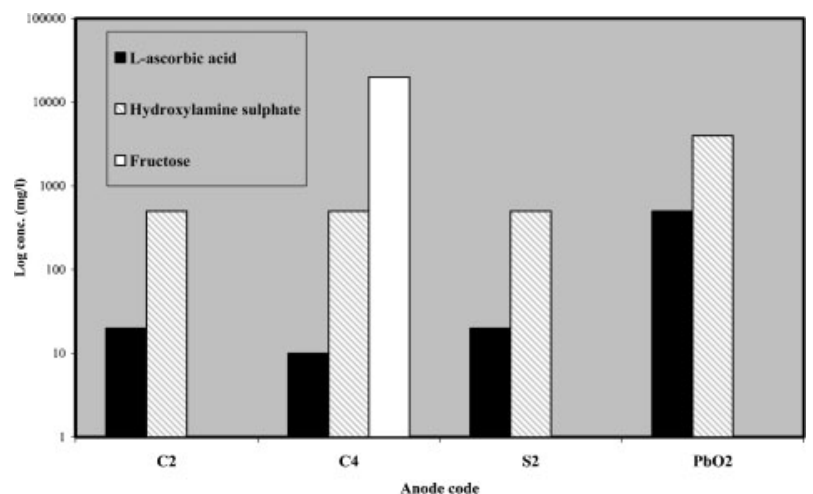

1 Limits of functionality of organic reductants on various anodes by Hull cell

\section{Brightener consumption study using HPLC}

Each of the organic reductants was tested at a concentration of $2 \mathrm{~g} \mathrm{~L}^{-1}$ in the plating cell and a control was performed whereby no organic reductants were present. The resultant brightener consumption rates are given in Table 2 and are illustrated graphically in Fig. 2. L-ascorbic acid caused a significant reduction in consumption rate for all four anodes, but the effect was most pronounced on anodes $\mathrm{C} 2$ and $\mathrm{C} 4$. Fructose only appeared to have a significant effect on brightener consumption when used with anode $\mathrm{C} 4$ while hydroxylamine sulphate had little if any effect on anodes $\mathrm{C} 4$ and $\mathrm{PbO}_{2}$, and only a slight one on anodes $\mathrm{C} 2$ and $\mathrm{S} 2$.

These results indicate that although sacrificial species such as L-ascorbic acid will reduce brightener consumption on a range of anodes, its functionality is affected by the nature of the anode.

\section{Anodic polarisation study}

The electrochemical behaviour of anode C2 (Fig. 3) seems to compare quite well with the observed functionality of the organic reductants in reducing brightener consumption. If the Hull cell and HPLC data from Tables 1 and 2 are considered then it can be seen that the order of functionality for these four species when using anode C2 is L-ascorbic acid $\gg$ hydroxylamine sulphate $>$ fructose

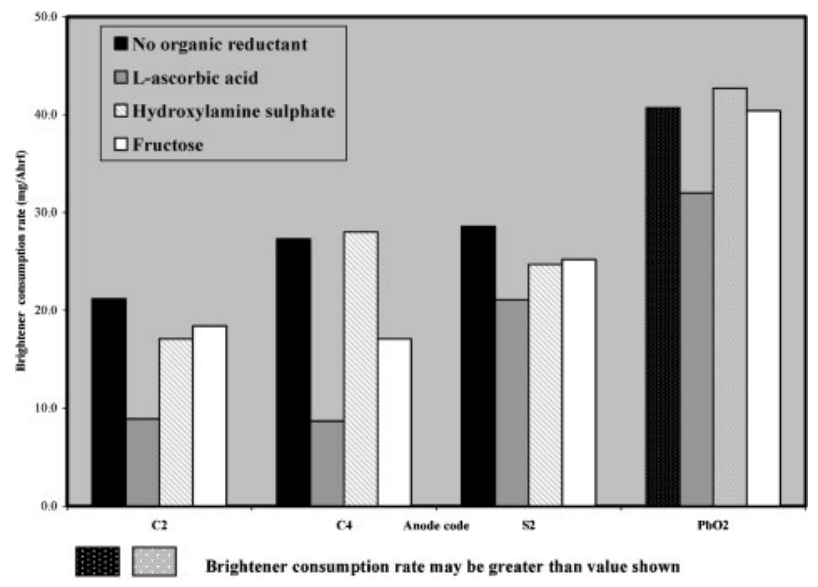

2 Effect of organic reductants $\left(2 \mathrm{~g} \mathrm{~L}^{-1}\right)$ on brightener consumption rate by HPLC

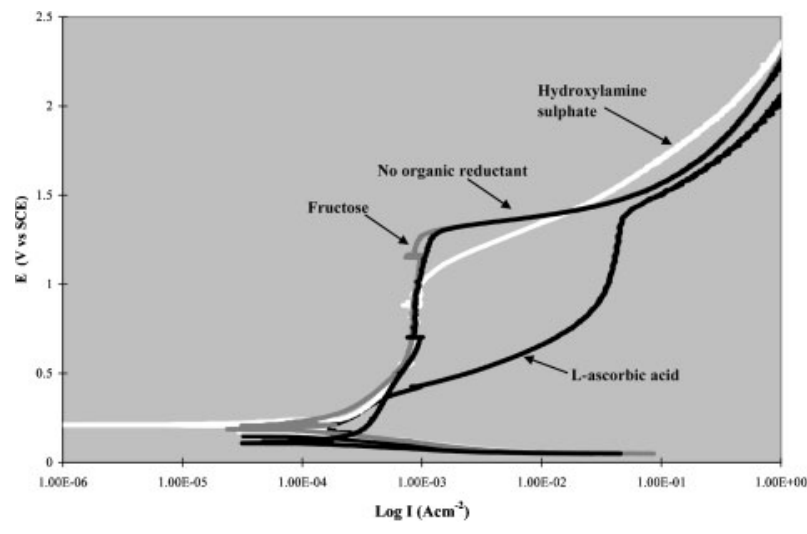

3 Anodic oxidation of various organic reductants $\left(10 \mathrm{~g} \mathrm{~L}^{-1}\right)$ at insoluble anodes: anode C2 (RDE)

Fructose was difficult to oxidise at anode $\mathrm{C} 2$ and hydroxylamine sulphate was only slightly better. Lascorbic acid was very readily oxidised.

If the same data for anode C4 are considered (Fig. 4, Tables 1 and 2) then a similar picture emerges for Lascorbic acid. However, the two techniques place hydroxylamine sulphate and fructose in different orders of functionality. The Hull cell test, implied that

Table 2 Effect of organic reductants $\left(2 \mathrm{~g} \mathrm{~L}^{-1}\right)$ on brightener consumption by HPLC

\begin{tabular}{llr}
\hline & & $\begin{array}{c}\text { Brightener } \\
\text { consumption rate, } \\
\mathbf{m g ~ A}^{-\mathbf{1}} \mathbf{h}^{-\mathbf{1}} \mathbf{L}^{-\mathbf{1}}\end{array}$ \\
\hline $\mathrm{C} 2$ & Organic reductant & $21 \cdot 2$ \\
$\mathrm{C} 2$ & none & $8 \cdot 9$ \\
$\mathrm{C} 2$ & L-ascorbic acid & $18 \cdot 4$ \\
$\mathrm{C} 2$ & Fructose & $17 \cdot 1$ \\
$\mathrm{C} 4$ & Hydroxylamine sulphate & $27 \cdot 3$ \\
$\mathrm{C} 4$ & none & $8 \cdot 7$ \\
$\mathrm{C} 4$ & L-ascorbic acid & $17 \cdot 1$ \\
$\mathrm{C} 4$ & Fructose & $28 \cdot 0$ \\
$\mathrm{~S} 2$ & Hydroxylamine sulphate & $28 \cdot 6$ \\
$\mathrm{~S} 2$ & none & $21 \cdot 1$ \\
$\mathrm{~S} 2$ & L-ascorbic acid & $25 \cdot 2$ \\
$\mathrm{~S} 2$ & Fructose & $24 \cdot 7$ \\
$\mathrm{PbO}_{2}$ & Hydroxylamine sulphate & $>40 \cdot 7$ \\
$\mathrm{PbO}_{2}$ & none & $32 \cdot 0$ \\
$\mathrm{PbO}_{2}$ & L-ascorbic acid & $>40 \cdot 4$ \\
$\mathrm{PbO}_{2}$ & Fructose & $42 \cdot 7$
\end{tabular}




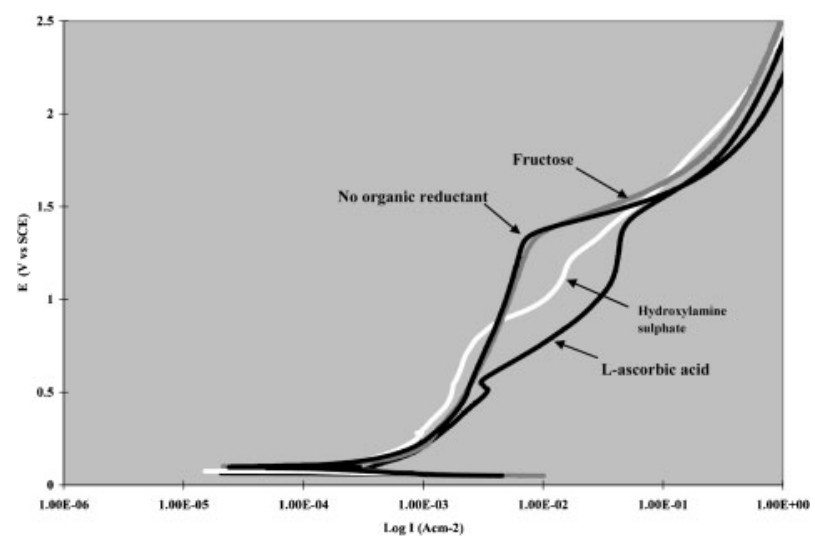

4 Anodic oxidation of various organic reductants at insoluble anodes: anode C4 (RDE)

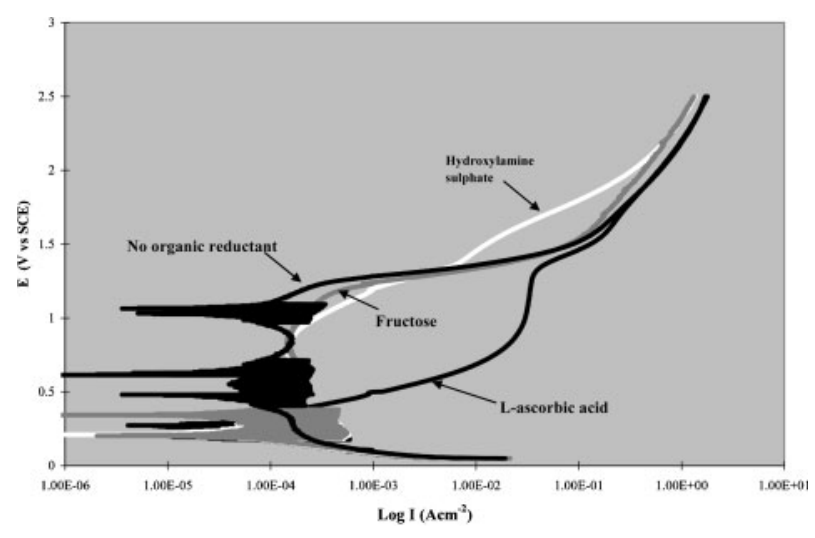

5 Anodic oxidation of various organic reductants at insoluble anodes: anode S2 (RDE)

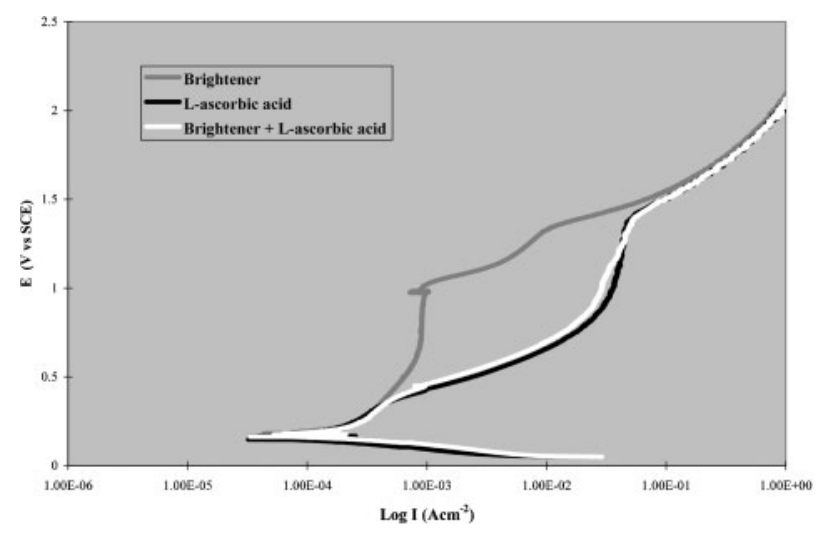

6 Effect of L-ascorbic acid on anodic oxidation of brightener anode C2 (RDE)

hydroxylamine sulphate is better at preventing brightener consumption than fructose, whilse the brightener consumption rates obtained from the HPLC work suggested that fructose reduced this consumption more than hydroxylamine sulphate. The explanation is probably related to the timescales of the respective experiments. The electrochemical results showed some evidence that fructose was oxidising at anode $\mathrm{C} 4$, but the lack of a definitive oxidation wave suggests that this is a very slow, difficult reaction. By contrast hydroxylamine sulphate had a clear oxidation wave with quite a high limiting current. It might be postulated, that hydroxylamine sulphate oxidises fairly rapidly at anode $\mathrm{C} 4$ and in an experiment with a short timescale its sacrificial

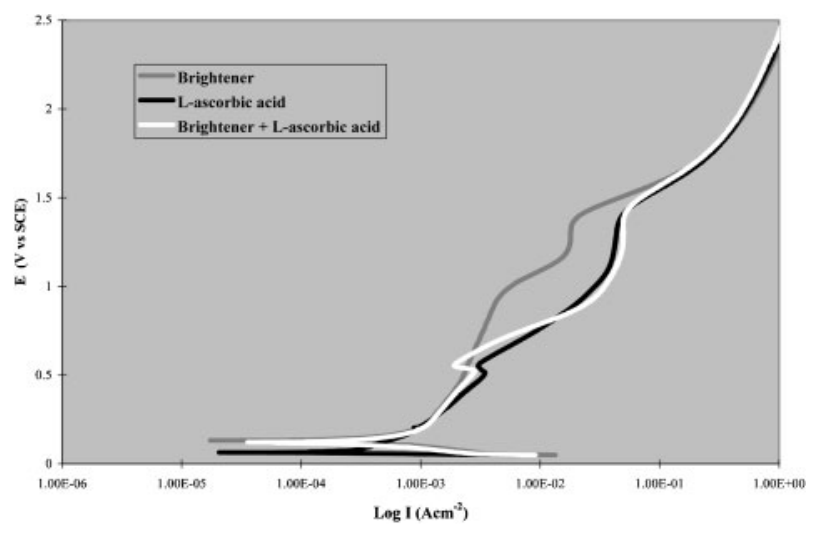

7 Effect of L-ascorbic acid on anodic oxidation of brightener anode C4 (RDE)

action would appear reasonably good. However, over longer plating times all the hydroxylamine sulphate would be quickly oxidised and its functionality lost. Plating for $30 \mathrm{~min}$ may therefore favour a slow oxidation such as might occur with fructose.

The Hull cell data for anode S2 (Table 1) again shows good correlation with the electrochemical data obtained from the polarisation curves (Fig. 5). The HPLC data, however, indicate that L-ascorbic acid is less efficient at preventing brightener oxidation on anode $\mathrm{S} 2$ as it is on the other two anodes. Of the three anode types tested, it is noticeable that anode $\mathrm{S} 2$ exhibits the lowest Tafel slope for L-ascorbic acid oxidation and this could mean that the reaction is kinetically more favourable on this anode than the other two. For this reason the timescale of the experiment would once more become a defining factor.

For all three anodes, L-ascorbic acid oxidation began at a low potential, with a relatively low Tafel slope, and limited at very high currents. One might therefore expect that this species would be rapidly oxidised and that its functionality would quickly deteriorate. The fact that this does not happen suggests that the mechanism by which L-ascorbic acid, reduces brightener consumption is not solely due to sacrificial oxidation.

Figures 6-8 show the effect of adding L-ascorbic acid to a brightener-containing electrolyte. It can be seen that for all three anodes, the presence of L-ascorbic acid caused the brightener oxidation wave to disappear.

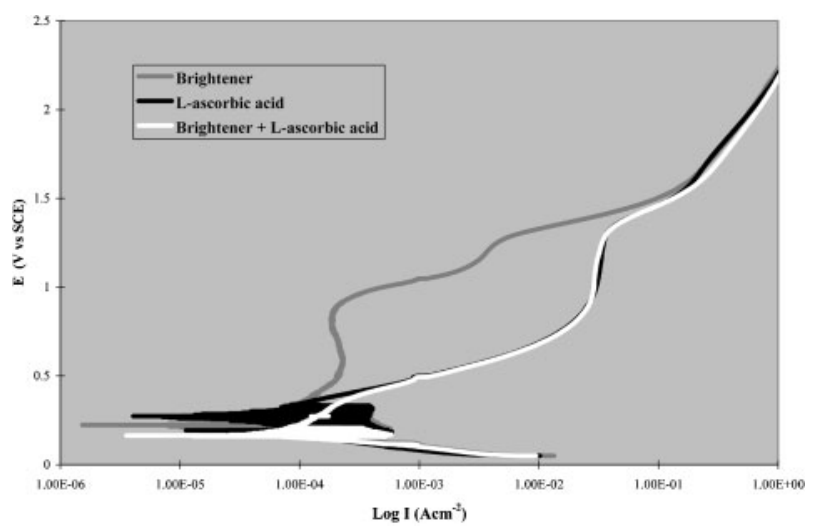

8 Effect of L-ascorbic acid on anodic oxidation of brightener anode - S2 (RDE) 


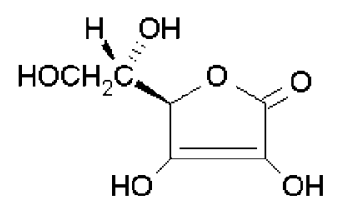

L-ascorbic acid

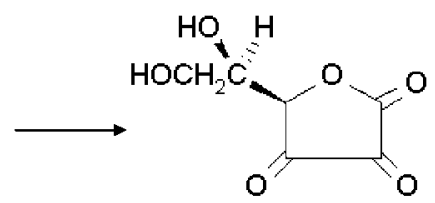

$+2 \mathrm{e}^{-}+2 \mathrm{H}^{+}$ Dehydroascorbic acid

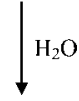

$\mathrm{COOH}$

C $=0$

$\mathrm{C}=\mathrm{O}$

$\mathbf{C}=\mathbf{O}$

СHOH

$\mathrm{CHOH}$

$\mathrm{CH}_{2} \mathrm{OH}$

Diketogulonic acid

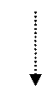

Oxalic acid + other acids

\section{Oxidation reactions of L-ascorbic acid}

\section{Discussion and conclusions}

It is clear from the results of this study that the addition of L-ascorbic acid to an acid copper electroplating solution utilising catalytic anodes will cause a significant reduction in brightener oxidation rate. Although the authors have not carried out any specific work into the mechanism by which this is achieved, it is proposed that it may be by one or more of the following pathways.

1. Sacrificial oxidation: the anodic polarisation scans described in this paper indicate that the oxidation of Lascorbic acid at catalytic anodes is both thermodynamically and kinetically more favourable than brightener oxidation. It is therefore possible that L-ascorbic acid may simply oxidise in preference to the brightener. However, the concentration at which it functioned (as low as $20 \mathrm{mg} \mathrm{L}^{-1}$ in the Hull cell test) suggests that this cannot be the only mechanism since, if it was, one would expect that large amounts of the organic reductant would have to be added to the electrolyte during the plating cycle to maintain low brightener oxidation rates.

2. Multistage oxidation: the anodic oxidation of Lascorbic acid has been studied on a range of different anodes and mechanisms involving several intermediate steps have been proposed ${ }^{13-17}$ in acid media (see Fig. 9). However, what is not disputed is that the final product of the electrochemical oxidation is dehydroascorbic acid which, under aqueous conditions, is then rapidly hydrolysed in a chemical reaction to diketogulonic acid. It is evident therefore that the products from the electrochemical and chemical oxidation of L-ascorbic acid can be further oxidised and this may help to explain why relatively low concentrations of L-ascorbic acid have a large effect on brightener oxidation rates. It is thought likely that L-ascorbic acid may be oxidised all the way to carbon dioxide, but if any organic species do remain which could influence the plating reaction (for example oxalic acid complexing copper ions in solution), then this underlines the importance of utilising
L-ascorbic acid at low concentrations, i.e. to ensure that any such effect is negligible.

3. Removal of oxidising species: the generally accepted mechanism ${ }^{18-20}$ for oxygen evolution from a metal oxide electrode involves the generation of highly oxidising species. Indeed, it has been proposed that it is the production of hydroxyl radicals from these anodes which make them very efficient for the destruction of organics in electrochemical waste water treatment. Lascorbic acid is a well known anti-oxidant and can also 'mop-up' free radicals and other oxidising species which might be generated at catalytic anodes. Quite clearly this behaviour would be expected to be of benefit in reducing the oxidation of brightener.

4. Selectivity and choice: it is clear that a number of organic reductants are effective in this mode of anode behaviour, ${ }^{8-12}$ study of which has at present been limited to acid copper sulphate solutions used in the PCB industry. The choice will depend upon several factors among which cost may be important but also the technological relationship between the oxidation and reduction potentials of the active species, i.e. brightener and reductant. It is obvious that other organic species present may also be concerned, e.g. levellers, surfactants, etc., but at present it is believed that these are intrinsically more stable and are less susceptible to anodic oxidation. Possible alternatives are listed in the associated patents ${ }^{8-12}$ and the availability of such compounds is an important consideration for any future process concern.

\section{References}

1. A. J. Cobley, D. R. Gabe and J. E. Graves: Trans. IMF, 2001, 79, (3), 112-118.

2. A. J. Cobley and D. R. Gabe: Trans. IMF, 2003, 81, (2), 37-44

3. A. J. Cobley and D. R. Gabe: Circuit World, 2001, 27, (3), 19-25.

4. A. J. Cobley and D. R. Gabe: Circuit World, 2003, 29, (4), 11-18.

5. H. Liebscher: DDR Patent 87-303566 870605, 1987.

6. J. Barthelmes: Proc. Conf. on 'Electronic circuit world convention',

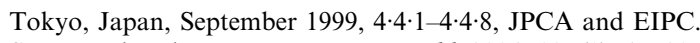

7. S. Menard and J. Wurm: Circuit World, 2004, 30, (3), 17-20.

8. A. J. Cobley, M. J. Kapeckas, E. Reddington, W. Sonnenberg, L. R. Barstad and T. Buckley: US Patent 6,911,068, 6,736,954 and $6,652,731,2005$

9. A. J. Cobley, M. J. Kapeckas, E. Reddington, W. Sonnenberg, L. R. Barstad and T. Buckley: EU Patent Publication 1300488, 2003.

10. A. J. Cobley, M. J. Kapeckas, E. Reddington, W. Sonnenberg, D. R. Gabe, L. R. Barstad, T. Buckley and J. E. Graves: EU Patent Publication 1300487, 2003.

11. A. J. Cobley, M. J. Kapeckas, E. Reddington, W. Sonnenberg, L. R. Barstad, T. Buckley and J. E. Graves: EU Patent Publication 1300486, 2003.

12. D. R. Gabe, A. J. Cobley, L. R. Barstad, M. J. Kapeckas, E. Reddington, W. Sonnenberg and T. Buckley: US Patent 6,773,573, 2005

13. F. Prieto, B. A. Coles and R. G. Compton: J. Phys. Chem. B, 1998, 102B, 7442-7447.

14. P. Karabinas and D. Jannakoudakis: J. Electroanal. Chem., 1984 160, 159-167.

15. J. Wu, J. Suls and W. Sansen: Electrochem. Commun., 2000, 2, 90 93.

16. M. Rueda, A. Aldaz and F. Sanchez-Burgos: Electrochim. Acta 1978, 23, 419-424.

17. P. Karabinas and D. Jannakoudakis: J. Electronal. Chem., 1984, 160, 159-167.

18. O. Simond, C. Comninellis and G. Foti: in 'Novel trends in electroorganic synthesis', 165-168; 1998, Tokyo, Springer-Verlag.

19. G. Foti, D. Gandini, C. Comninellis and A. Perret: Electrochem. Solid-state Lett., 1999, 2, (5), 228-230.

20. C. Bock and B. MacDougal: J. Electrochem. Soc., 1999, 146, (8), 2925-2932. 